\title{
Hyperspectral analysis of shale gas drilling in southern Huangling anticline
}

\author{
Liu Pengfei ${ }^{1, *}$, Zhao Yingjun ${ }^{1}$, Guo Tianxu ${ }^{2}$, Zhang Hongda ${ }^{2}$ \\ ${ }^{1}$ National Key Laboratory of Remote Sensing Information and Image Analysis Technology, Beijing Research Institute of Uranium \\ Geology, Beijing 100029, China \\ ${ }^{2}$ China Geological Survey Oil and Gas Resources Investigation Center, Beijing 100083, China
}

\begin{abstract}
In this paper, the visible near infrared, short wave red, and thermal infrared spectral data and highdefinition core images of three wells in Huangling anticline in Western Hubei are obtained by hylogger. Through comprehensive analysis, it can be seen that the thickness of Niutitang Formation is decreasing from west to East, However, the thickness of Doushantuo Formation is basically the same, ranging from $210 \mathrm{~m}$ to $220 \mathrm{~m}$. Quartz, clay minerals, carbonate and limonite are the main minerals in Niutitang formation, while in Doushantuo Formation dolomite is the main mineral. Dolomite fracture is developed in this area, which is a favorable area for shale gas development.
\end{abstract}

\section{Background}

Shale gas refers to the mature dark shale or high carbon shale which is rich in organic matter, because of the adsorption of organic matter or the existence of cracks and matrix pores in the rock, which makes the reservoir and preservation of natural gas with certain commercial value of biogenic, pyrolytic and mixed origin ${ }^{[1]}$.

In recent years, the growth rate of domestic natural gas consumption demand has exceeded that of coal and oil, and the external dependence is rising rapidly. The gap between supply and demand is also getting bigger and bigger, especially the short-term imbalance between supply and demand, which has affected the safety of urban gas supply and the improvement of people's living environment. However, the contradiction between supply and demand cannot be effectively alleviated only by increasing the production of conventional natural gas. Therefore, it is urgent to strengthen the exploration and exploitation of shale gas, increase the production of shale gas in China, and form an effective supplement to conventional natural gas.

Hyperspectral core survey obtains the hyperspectral core data, extracts the mineral information to analyze the vertical spatial distribution characteristics of drilling, and provides guidance for shale gas exploration work.

In this paper, visible-near-infrared, short-wave red, and thermal infrared spectral data and core high-definition images of four drilling Wells in Huangling anticline in western Hubei were obtained through Hylogger. By extracting mineral information from the hyperspectral data, a comprehensive analysis was made on the four drilling Wells.

\section{Geological background in Huangling anticline, western Hubei}

The southern wing of the Huangling anticline belongs to continental shelf platform facies. In the Late Sinian, Doushantuo Formation, a set of source rocks composed of black shale, dark grayish black micritic limestone and carbon-bearing mudstone, was divided into a second-order sequence (SS1), which contains four third-order sequences (SQ1 SQ2 SQ3 SQ4). The high quality dark shale is mainly distributed in the SQ2 sequence, namely the second member of Doushantuo Formation of the Upper Sinian ${ }^{[2]}$. The Doushantuo Formation in this area is mainly composed of favorable interplatform depression facies. The main lithology of the second member of Doushantuo Formation is carbonaceous micritic limestone and dolomite, and the organic matter type is mainly sapropelic (Itype) or humic sapropelic (IItype). The content of organic matter was in the range of $0.55 \%$ $2.23 \%$, with an average of $1.4 \%$. Ro ranged from $1.49 \%$ to $1.86 \%$, with an average of $1.74 \%$, which was basically in the over-mature stage ${ }^{[3]}$.

\section{Analysis of individual drilling}

Absorption band position (P) is the wavelength corresponding to the minimum or maximum value of the spectral curve; spectral to emissivity value $(\mathrm{R})$ at the absorption band position; band depth $(\mathrm{H})$ is due to the fact that mineral chemical composition has lower emissivity at a certain wavelength point than the adjacent band; width (W) refers to the depth of the band H. Half the height; slope $K=\tan ^{-1}[(\operatorname{Re}-\mathrm{Rs}) /(\lambda \mathrm{e}-\lambda \mathrm{s})]$. The sketch of

* Corresponding author: figerol@126.com 
characteristic parameters of mineral absorption is shown in the following figure ${ }^{[4]}$.

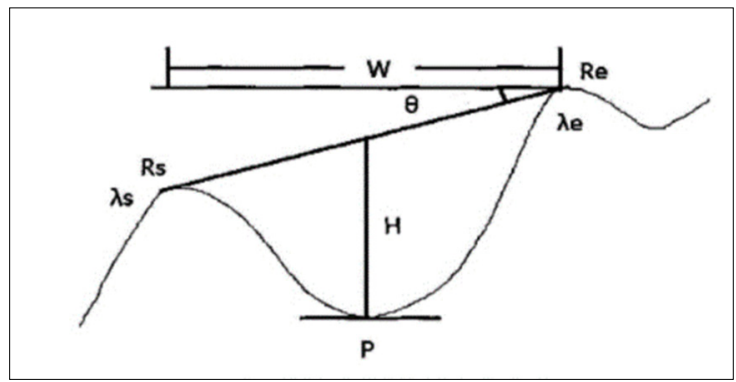

Fig.1.Spectral Absorption Characteristic

Among them, Re ,Rs are the absorption endpoint and the incidence of absorption starting point respectively: the corresponding wavelength is $\lambda \mathrm{e}, \lambda \mathrm{s}$.

In this paper, the core scanning of YY1, ZD1 and ZD2 shale gas wells in the lower Cambrian Niutitang Formation and the lower Sinian Doushantuo Formation was completed by using the hylogger core scanner, and the hyperspectral and high-definition image data of visible near infrared short wave infrared $(380-2500 \mathrm{~nm})$ and thermal infrared (6000-14500nm) were obtained.

The rock types of Niutitang Formation are mainly dolomitic rock, silty mudstone, black mudstone and black shale.

The main rock types of Doushantuo Formation are: gray-black mudstone, siltstone, fine sandstone and dolomite.

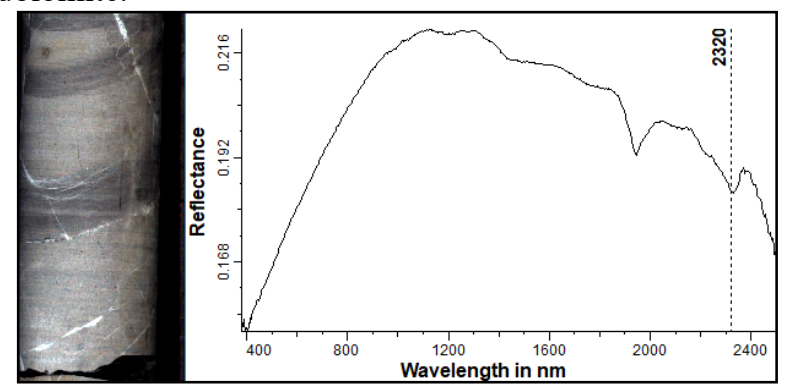

Fig. 2. Image and spectrum of dolomitic mudstone cores

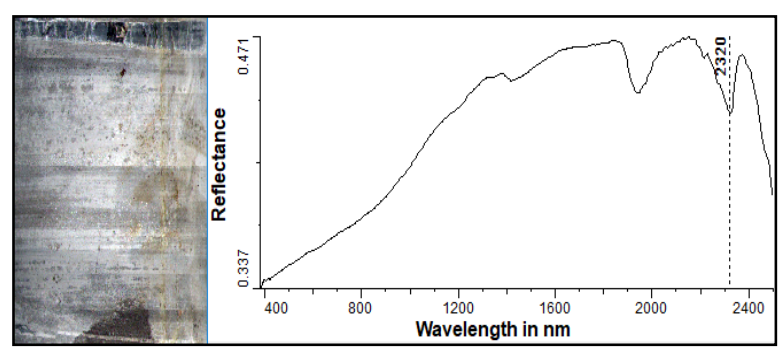

Fig. 3. Image and spectrum of iron dolomite core

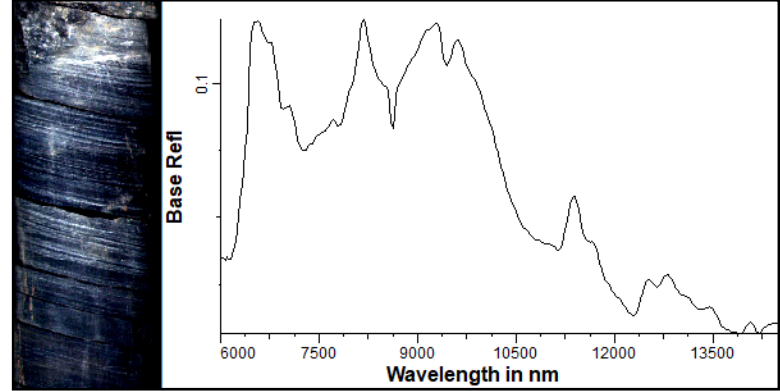

Fig. 4. Image and spectrum of black shale core from well ZD1

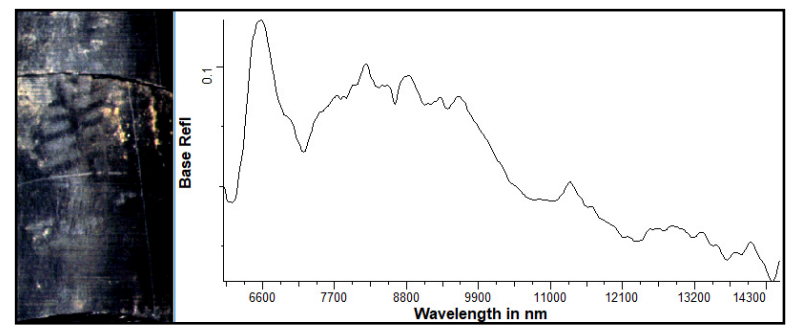

Fig. 5. Image and spectrum of black mudstone cores

\subsection{Mineral information distribution in well ZD1}

68.94m-439.54m: Quartz has a small distribution in this section, mainly distributed in the range of $191.66 \mathrm{~m}$ to $359.06 \mathrm{~m}$, and the relative content reaches $100 \%$ in many places in this section.

Kaolinite is concentrated in the range of $326 \mathrm{~m}-354 \mathrm{~m}$ in this section, and its relative content is small, with the maximum relative content of $37.2 \%$, located at $351.02 \mathrm{~m}$.

Calcite is continuously distributed in large quantities in this section, and its relative content is high. It is the main alteration mineral, and the relative content reaches $100 \%$ in many places. The dolomite is widely distributed in this section, which mainly concentrates in the beginning and end of this section, with the maximum relative content of $100 \%$, appearing in many places.

Chlorite is distributed continuously in this section, but its relative content is low, basically below $20 \%$. The maximum relative content is $66.2 \%$, which is located at $67.92 \mathrm{~m}$.

Sulfate, Muscovite, montmorillonite, Illite are rarely distributed in this section.

569.04m-861.86m: Quartz is mainly distributed continuously in the range of $665.34-861.86 \mathrm{~m}$ in this section, and its content has no obvious change compared with that in the previous section. Its relative content curve fluctuates greatly, and the relative content is $100 \%$ in several areas.

Calcite is continuously distributed in large quantities at the beginning and end of this section, and its relative content is high, and the relative content reaches $100 \%$ in many places. The dolomite is continuously distributed in large quantities in this section, which is the main alteration mineral with the maximum relative content of $100 \%$ and appears in many places.

Chlorite is distributed continuously in this section, but its relative content is low, basically below $20 \%$. It is mainly located after $686 \mathrm{~m}$, and the maximum relative 
content is $91.8 \%$, located at $760.62 \mathrm{~m}$.

Sulfate, Kaolinite, Muscovite, Montmorillonite, Ilite are rarely distributed in this section.

\subsection{Mineral information distribution in well ZD2}

664.54m-841.64m: Quartz is widely distributed at the beginning and end of this section, and the relative content reaches $100 \%$ in many places in this section. Calcite is continuously distributed in this section, and the relative content of calcite increases obviously in the range of $732.84 \mathrm{~m}$ to $817.66 \mathrm{~m}$, showing a negative correlation with quartz.

Dolomite is distributed continuously after $731.82 \mathrm{~m}$ in this section, and the maximum relative content is $85.9 \%$, which is located at $818.36 \mathrm{~m}$.

Chlorite is distributed continuously in this section, but its relative content is low, basically below $40 \%$, and the maximum relative content is $71.2 \%$, which is $766.4 \mathrm{~m}$.

The distribution of amphibole, feldspar, gypsum, Muscovite, montmorillonite and illite are rarely distributed in this section.

1158.06m-1445.81m: Quartz is distributed discretely in this section, and its content is obviously less than that of the above section, and its relative content reaches $100 \%$ in many places in this section.

In the range of $1158.06 \mathrm{~m}$ to $1027.66 \mathrm{~m}$, the calcite is continuously large, while the distribution of the remaining sections is significantly less, and the relative content in many parts of this section reaches $100 \%$.

Dolomite is continuously distributed in large quantities in this section, and it is the main alteration mineral, with the maximum relative content of $100 \%$ and dense occurrence.

Chlorite has been continuously distributed since the late section of $1197.56 \mathrm{~m}$, and the maximum relative content is $73.1 \%$, which is located at $1426.24 \mathrm{~m}$.

Hornblende, gypsum, Muscovite, montmorillonite are rarely distributed in this section.

\subsection{Mineral information distribution in well YY1}

2971.24m-3066.9m: Quartz is continuously distributed in this area, and the maximum relative content of quartz is $100 \%$.

The distribution of calcite is relatively discrete, with continuous distribution at the front and rear ends of the section, and the distribution at other locations is relatively discrete, with the maximum relative content reaching $100 \%$ in many places; dolomite is widely distributed, with the relative content smaller than that of quartz in front, with the maximum relative content reaching $100 \%$ in many places.

Chlorite is widely distributed, and its distribution increases obviously, with the maximum relative content of $60.8 \%$ at $3012.86 \mathrm{~m}$.

Muscovite, amphibole and montmorillonite are rarely distributed in this section.

3329.08m-3453.02m: Quartz is continuously distributed in this area, and the maximum relative content of quartz is $100 \%$.
Calcite is sporadically distributed before $3421.46 \mathrm{~m}$, and continuously distributed after $3421.46 \mathrm{~m}$, with the maximum relative content of $91.9 \%$ at $3442.24 \mathrm{~m}$; dolomite is densely distributed with high relative content, with the maximum relative content of $100 \%$.

Muscovite, amphibole, montmorillonite, chlorite are rarely distributed in this section.

\section{Comparative analysis of mineral information of zd1, ZD2 and YY1}

Wells in the western Hubei area belong to the middle and upper Yangtze region. Wells ZD1, 2 and YY1 are located in the south of Huangling anticline, This paper makes a comparative analysis of these Wells.

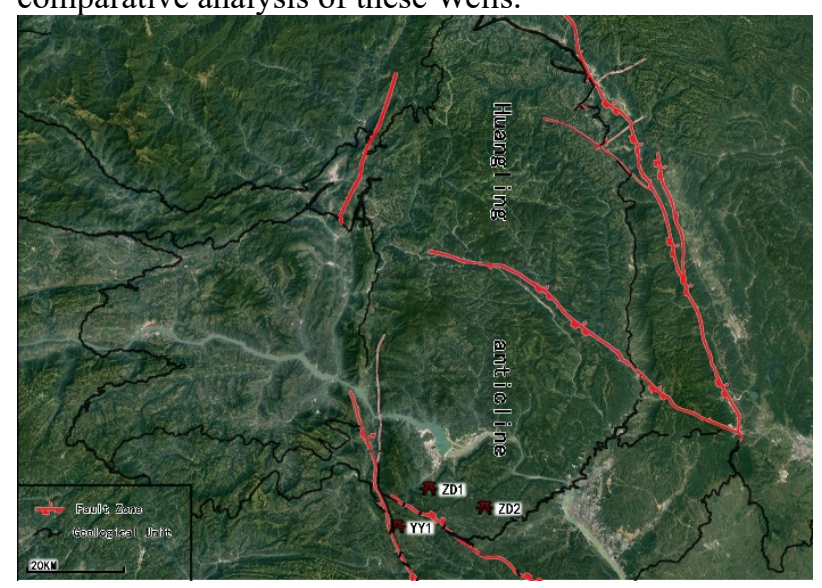

Fig. 6. Drilling distribution map

Table 1. Depth of each drilling target layer

\begin{tabular}{|c|c|c|}
\hline $\begin{array}{l}\text { Name of } \\
\text { drilling }\end{array}$ & $\begin{array}{c}\text { Depth of Niutitang } \\
\text { Formation }\end{array}$ & $\begin{array}{c}\text { Depth of Doushantuo } \\
\text { Formation }\end{array}$ \\
\hline YY1 & $\begin{array}{c}2601 \mathrm{~m}- \\
3069.5 \mathrm{~m}(468 \mathrm{~m})\end{array}$ & $3245 m-3458 m(213 m)$ \\
\hline ZD1 & $\begin{array}{c}66.31 \mathrm{~m}- \\
386.46 \mathrm{~m}(320.15 \mathrm{~m})\end{array}$ & $\begin{array}{c}633.91 \mathrm{~m}- \\
854.16 \mathrm{~m}(220.97 \mathrm{~m})\end{array}$ \\
\hline ZD2 & $\begin{array}{c}734.5 \mathrm{~m}- \\
817.52 \mathrm{~m}(83.02 \mathrm{~m})\end{array}$ & $\begin{array}{c}1234.95 \mathrm{~m}- \\
1445.0 \mathrm{~m}(210.05 \mathrm{~m})\end{array}$ \\
\hline
\end{tabular}

Among the three Wells, the thickness of Niutitang Formation in Well YY1 is the largest, and that in Well ZD2 is the smallest. It can be seen that the thickness of Niutitang Formation decreases from west to east. The thickness of Doushantuo Formation is basically the same in the three Wells, ranging from $210 \mathrm{~m}$ to $220 \mathrm{~m}$.

In Niutitang Formation, quartz, clay minerals, carbonate and trivalent iron are the main minerals, which are basically the same as those in three wells in Huangling anticline. Well ZD1 and well ZD2 are dominated by dolomitic mudstone and siltstone at the top and bottom, but in dark layer system, well ZD1 and well ZD2 are basically the same as well YY1. 


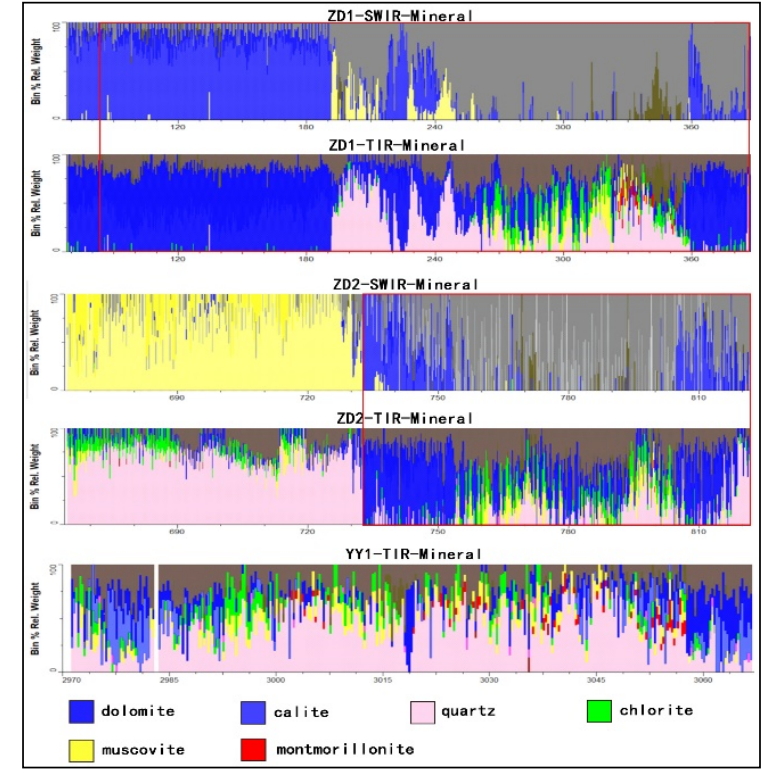

Fig. 7. Mineral content contrast map of Niutitang Formation

In Doushantuo Formation, dolomitic rocks are the main minerals in well ZD1, well ZD2 and well YY1. The difference is that the quartz content of well ZD1 and well YY1 is higher than that of well ZD2 except trivalent iron, and the clay mineral content of well ZD1 and well YY1 is higher than that of well YY1.

Dolomitization of carbonate rock often increases the size of crystal and the radius of inter pore channels, so as to improve the permeability and form a good reservoir. The dolomite fractures in the three wells are developed, which is conducive to fracturing and is a good gas reservoir.

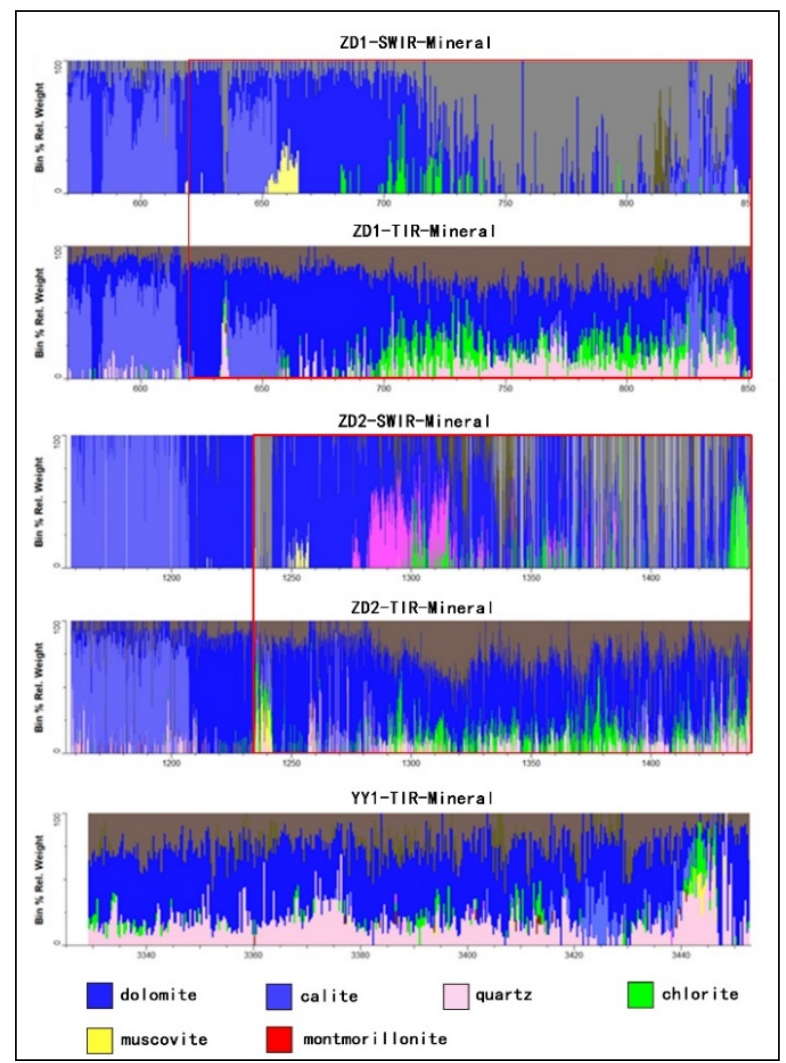

Fig. 8. Mineral content contrast map of Doushantuo Formation
After the extraction of al-oh absorption peak (the mica content in YY1 well is very little, so no map is made), it is found that the absorption peak of aluminum hydroxyl group is after $2210 \mathrm{~nm}$ and has little change, which belongs to low aluminum sericite, indicating that the temperature environment in this area is relatively stable.

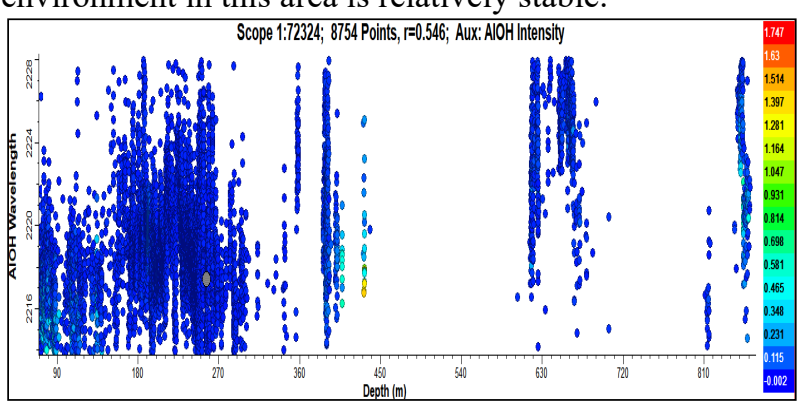

Fig. 9. Location of AL-OH absorption peak in well ZD1

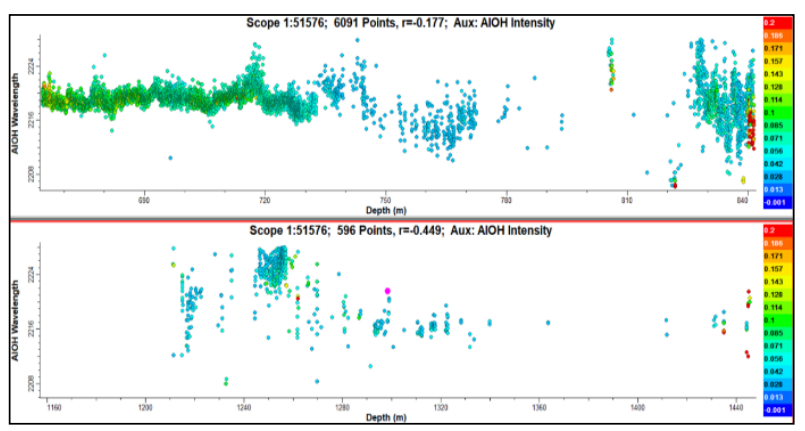

Fig. 10. Location of AL-OH absorption peak in well ZD2

\section{Conclusion}

The lithology of ZD1 well is mainly dolomitic limestone, dolomite, black shale, mudstone and dolomitic limestone. The main lithology of ZD2 well is gray black silty mudstone, black mudstone, dolomite, dolomitic siltstone and black dolomitic mudstone. The lithology of YY1 well is mainly gray black and black mudstone, gray black and black shale and dolomite.

The dolomitization of carbonate rocks often increases the size of the crystals and the radius of the pore channels, thus improving the permeability and forming good reservoirs. The fractures in the dolomite in these three Wells are well developed and the characteristics of hydrocarbon absorption peaks are obvious, which is conducive to fracturing and is a good reservoir horizon.

\section{References}

1. Wang $\mathrm{X}$,Liu $\mathrm{YH}$, Zhang $\mathrm{M}$, et al. Conditions of Formation and Accumulation for shale Gas[J].Natural Gas Geoscience,21(02) : 350-356 (2010)

2. Shan CA, Zhang TS, Guo JJ, et al. Geolo-gical characteristics and resource potential of the Upper Sinian Doushantuo Formation shale gas in the north of Middle Yangtze region[J].Geology in China,42(6) : 1944-1958(2015)

3. Li XB, Chen MK, Liu A, et al . Evaluation of accumulation system for shale gas of Doushantuo 
Formation in west-ern Xuefeng Mountain[J]. Petroleum Geolog\&Experiment,36 (2): 188 193(2014).

4. Su HJ, Du PJ, Sheng YH, Study on feature extraction and experiment of hyperspectral data[J], Application Research of Computers, (02):390-394(2008). 